\title{
Recent Growth and Expansion of Birch Shrubs Across a Low Arctic Landscape in Continental Canada: Are These Responses More a Consequence of the Severely Declining Caribou Herd than of Climate Warming?
}

\author{
Rhett Andruko, ${ }^{1}$ Ryan Danby, ${ }^{2} \odot$ and Paul Grogan ${ }^{1 *} \odot$
}

${ }^{1}$ Department of Biology, Queen's University, Kingston, Ontario K7L 3N6, Canada; ${ }^{2}$ School of Environmental Studies, Queen's University, Kingston, Ontario K7L 3N6, Canada

\begin{abstract}
The recent widespread expansion of deciduous shrubs across much of the Arctic has been largely attributed to climate warming. This study investigated decadal growth rates of dwarf birch (Betula glandulosa) across a low Arctic landscape in the continental interior of Canada. Detailed birch cover $\left(100 \mathrm{~m}^{2}\right.$ replicate plots) and individual shrub stature measurement datasets for five representative habitat-types were compared between 2006 and 2016, and evaluated in relation to environmental
\end{abstract}

Received 2 August 2019; accepted 8 December 2019; published online 9 January 2020

Electronic supplementary material: The online version of this article (https://doi.org/10.1007/s10021-019-00474-7) contains supplementary material, which is available to authorized users.

All data in this study are accessible via the Polar Data Catalogue metadata website (https://www.polardata.ca).

Authors Contributions: PG conceived and designed the study. RA collected and analyzed the data. PG, RA, and RD wrote the manuscript.

*Corresponding author; e-mail: groganp@queensu.ca characteristics. Furthermore, dendrochronologically-based annual growth rates were assessed in relation to the 20-year climate record. Birch height, lateral dimensions, and patch groundcover all increased $20-25 \%$ relative to 2006 values, but these increases were similar among the habitat-types. Together, the limited evidence of recent warming at this site, the absence of significant habitat-type growth rate differences, and the lack of correlation between annual climate and stem secondary growth strongly suggest that climate change was not the principal cause. Instead, we propose that release from caribou impacts following the recent severe herd decline may explain the net shrub growth. Individual shrub growth rates were correlated with soil nutrient availability, but the latter was highly variable, suggesting that growth rates are primarily determined by fine-scale rather than habitat-scale spatial heterogeneity in nutrient supply. Together, our results demonstrate that birch growth has been enhanced across a variety of habitat-types in the Daring Lake landscape over the decade since 2006, and suggest that the recent severe caribou herd declines may be at least as 
significant as climate warming in driving birch shrub expansion in the Canadian central low Arctic.
Key words: birch; deciduous shrub; Arctic tundra; climate change; caribou; herbivory; trampling; groundcover; soil nutrients; soil moisture.

\section{HighLights}

- Birch growth and cover across diverse habitattypes have increased by about 25\% since 2006 .

- Recent climate warming trends at this low Arctic continental interior site are limited.

- Release from caribou impacts due to herd decline may explain the enhanced growth.

\section{INTRODUCTION}

\section{Recent Increases in Arctic Deciduous Shrub Growth: Patterns and Implications}

The Arctic is currently undergoing many fundamental changes, one of which is an increase in vegetation productivity that has been widely attributed to climate warming (Comiso and Hall 2014; IPCC 2013). "Greening" has been observed in many locations across the low Arctic tundra of North America in the past 30 years, but especially in coastal and near-coastal regions such as northern Alaska, the northwest coast of Canada, and northern Quebec and Labrador (Beck and Goetz 2011; Ju and Masek 2016). By contrast, these satellite-based studies indicate that there has been relatively little, and very patchy, vegetation greening in more inland tundra regions such as the central and eastern Canadian Arctic (that is, the central Northwest Territories to Nunavut) (Ju and Masek 2016; Bonney and others 2018). Either vegetation change has not occurred over the past 30 years in many areas within the interior continental region, or it is slow and patchy across the landscape and often not detectable because of the low spatial resolution ( $30 \mathrm{~m}$ pixels) of the satellite data available for that period. Furthermore, although these remote sensing observations have been largely supported by various ground-truthing studies in near-coastal Arctic regions (Myers-Smith and others 2011), there has been very little corresponding on-the-ground research within the continental interior.

Increases in the groundcover, density, and stature of deciduous shrub species (Betula spp., Alnus spp., Salix spp.) are the primary explanation for the recent trends in Arctic land surface 'greening' (MyersSmith and others 2011). Given that these species are often the physically dominant vegetation over much of the low Arctic, their increased growth could result in a number of important feedbacks, both within the ecosystem itself and to the climate as a whole. First, tall deciduous shrub canopies accumulate snow that insulates their underlying soils overwinter, significantly restricting heat loss and winter soil temperature minima that can promote permafrost thaw (Tape and others 2006; Myers-Smith and Hik 2013). Enhanced microbial decomposition of Arctic soil organic matter as a result of warmer winter soils and permafrost thaw could release large quantities of greenhouse gases, including $\mathrm{CO}_{2}$ and $\mathrm{CH}_{4}$ (Schuur and others 2015). Second, areal expansion and vertical extension of deciduous shrub canopies can alter the overall energy balance of tundra terrestrial ecosystems by reducing land surface albedo (reflectance of incoming solar radiation), resulting in earlier snowmelt and warmer local air masses that would amplify the effects of climate change in the Arctic (Chapin and others 2005). Third, deciduous shrub canopies strongly influence the overall composition and structure of vegetation communities in Arctic tundra. Deciduous shrubs shading of understory communities can significantly reduce plant species richness (Pajunen and others 2011 ), but their extensive height and woody structure may also protect the understory from large herbivore impacts, thereby enhancing richness (Bråthen and Lortie 2016). They also enhance soil nitrogen availability through their effects on soil microclimate and their relatively large litter production (Buckeridge and others 2010; DeMarco and others 2011; Vankoughnett and Grogan 2016), promoting their own growth and inhibiting neighboring plant species such as evergreens that are not as well adapted to elevated soil fertility (Zamin and others 2014).

\section{Factors Affecting Net Deciduous Shrub Growth in Arctic Tundra}

Climate change, reduced herbivore populations (for example, of voles, hares, and caribou), and recovery from ecosystem disturbances (for example, fire, permafrost degradation, human disturbance) are the three main factors that can drive phases of net growth (that is, sustained biomass increases over multiple years) in established 
deciduous shrubs (Myers-Smith and others 2011). We developed a conceptual framework that includes these principal factors, but also specifically incorporates the potential mediating influence of habitat-type, as well as the main interactions between climate change and the other main factors (Figure 1). For example, climate change could directly affect shrub growth through warming-enhanced photosynthesis, and/or it could alter soil fertility, soil moisture or snow depth, indirectly affecting shrub growth. Furthermore, the potential effects of climate change on these environmental components may vary in magnitude, and even direction, depending on the distinctive characteristics of each particular deciduous shrub habitattype (Figure 1). In terms of interactions, climate change could promote disturbance events (for example, permafrost thaw) that may subsequently stimulate shrub growth. Finally, climate change could reduce or enhance herbivore population sizes, resulting in a decrease or increase, respectively, in their top-down regulatory impacts (that is, direct consumption of plant tissue, but also trampling damage in the case of large mammals such as caribou) on shrub net growth (Figure 1).

Of the three principal factors, ongoing regional climate warming is generally assumed to be the main factor driving the satellite, landscape repeat photography and dendrochronologically based reports of enhanced deciduous shrub growth across much of the low Arctic (for example, Ju and Masek 2016; Tape and others 2012; Tremblay and others
2012; Ropars and others 2017). Furthermore, meta-analyses of standardized experimental warming treatments across the Arctic have provided rigorous evidence that deciduous shrub growth can be significantly enhanced by elevated summer temperatures (Walker and others 2006; Elmendorf and others 2012a).

However, the factors that affect the growth rates of individual shrubs in response to warming remain poorly understood, and large-scale meta-analyses of recent changes in tundra shrub communities indicate considerable spatial heterogeneity in growth rates that is attributed not just to variability in temperature trends, but also to soil moisture differences (Elmendorf and others 2012b). Low Arctic tundra landscapes are highly diverse, with distinct topographically-determined gradients of vegetation ranging from the sparse, low plant cover on the tops of exposed dry ridges to the thick, tall shrub canopies within wind-protected watercourse channels or on valley stream slopes and floodplains. Snow accumulation and subsequent meltwater inputs and flows in spring, wind exposure, and the soil's depth and moisture-holding characteristics also vary substantially across these gradients (Giblin and others 1991) resulting in strong soil fertility differences between adjacent tundra habitat-types (Björk and others 2007; Chu and Grogan 2010). Therefore, the particular habitattype associated with topographic location may be an important underlying factor determining the growth responses of individual shrubs to warming,

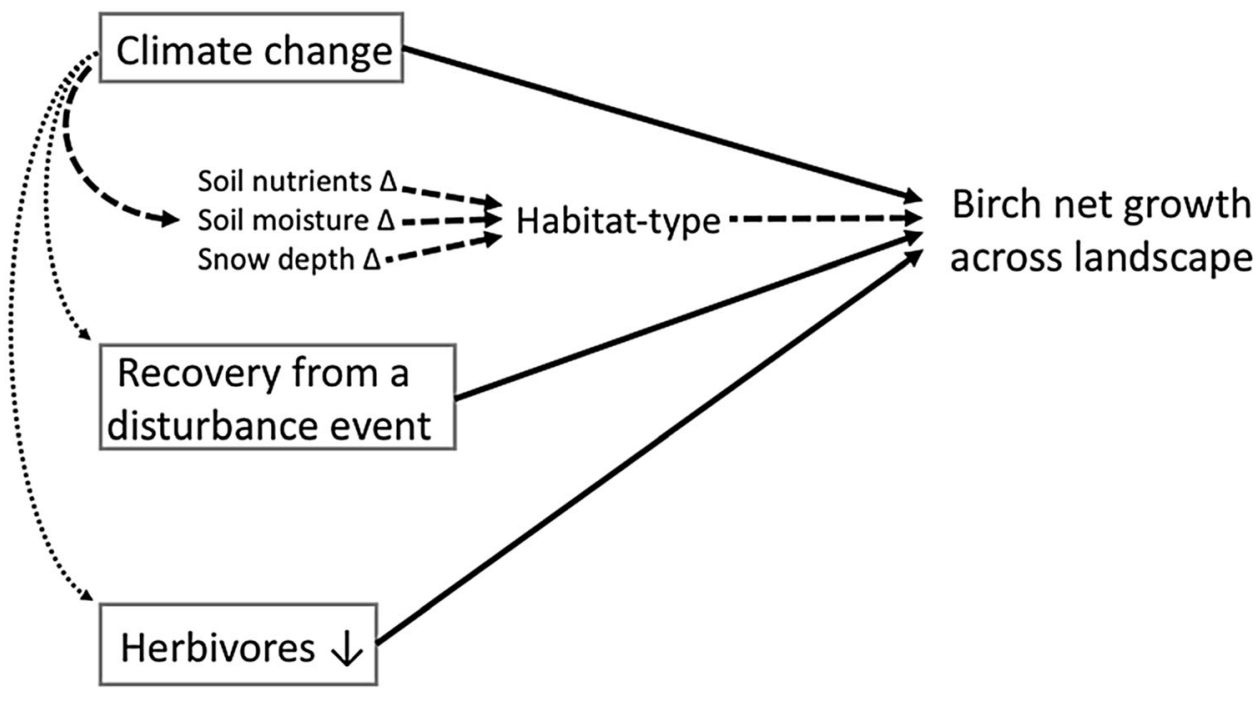

Figure 1. A conceptual framework of the three principal factors (gray boxes) that can directly determine landscape-scale patterns of net decadal growth in tundra deciduous shrubs (such as birch). Climate change can indirectly affect deciduous shrub growth by altering environmental features of habitat-type (thick dashed black lines; $\Delta$ indicates change), and can also exert significant interaction effects on the other two principal factors (thin dotted lines; see text for details). 
and hence of the overall landscape-scale patterns of shrub growth responses.

Indeed, most previous repeat photography and dendrochronological studies have generally concluded that tundra deciduous shrub growth responses to recent warming differ according to habitat-type (Tape and others 2006; Naito and Cairns 2011; Tape and others 2012; Tremblay and others 2012; Ropars and Boudreau 2012; Blok and others 2011; Ropars and others 2015; Cameron and Lantz 2016; Young and others 2016; Ackerman and others 2017). For example, in response to recent warming, alder (Alnus) shrub patches in relatively nutrient-rich habitat-types (for example, in floodplains and stream corridors) have tended to exhibit net growth and expansion, whereas those in more nutrient-poor habitat-types (for example, along ridges) have tended to remain stable (Tape and others 2012). However, the mediating influence of habitat-type on deciduous shrub growth rates has only been explicitly demonstrated in a few studies (cited above), all of which were in tundra regions where significant recent climate warming and greening are occurring — such as northern Alaska, northern Quebec, and the northern mainland coast of Canada-while none were located in continental interior regions such as the central Canadian Arctic.

Our study focused specifically on the deciduous shrub dwarf birch (Betula glandulosa Michx.hereafter referred to as "birch") as it is the most dominant component of erect shrub canopies in the low Arctic's continental interior (Porsild and Cody 1980; CAVM 2003). Birch shrubs are particularly interesting in terms of deciduous shrub net growth dynamics because they have the ability to quickly allocate resources to lateral shoots under favorable conditions, allowing them to dominate several tundra communities when and where soil fertility is enhanced (Bret-Harte and others 2001). We studied birch growth rates in a variety of its habitat-types at the Daring Lake site which is located in the central Canadian low Arctic and is also close to the center of the Bathurst caribou herd's annual migratory range (Figure 2). Our research addressed the following specific questions:

1. Have there been net increases in birch shrub groundcover and stature (that is, height, lateral dimensions, branch length) across the Daring Lake landscape from 2006-2016, and if so, did the increases differ among habitat-types?

2. Do dendrochronologically-based birch stem growth rates correlate with either interannual variations or longer-term climate trends at Daring Lake?
3. Can habitat-type differences in environmental factors such as soil moisture and nutrient availabilities be used to predict growth rates of individual birch shrubs?

\section{MethodS}

\section{Study Site}

This study was performed near the Tundra Ecosystem Research Station (TERS) at Daring Lake, Northwest Territories $\left(64^{\circ} 52^{\prime} \mathrm{N}, 111^{\circ} 33^{\prime} \mathrm{W}\right)$ (Figure 2). A meteorological station has been operated by Kokelj and others (Water Management and Monitoring Division of the Department of Environment and Natural Resources, Government of Northwest Territories) at TERS since 1996. Measured daily mean air temperatures range from about $14^{\circ} \mathrm{C}$ in July to about $-29^{\circ} \mathrm{C}$ in January, and the landscape is typically covered in snow from October to May. Monthly average temperature data from the station exhibit strong, positive correlations with records from the nearest Environment and Climate Change Canada (ECCC) meteorological stations at Yellowknife $(r=0.990$,

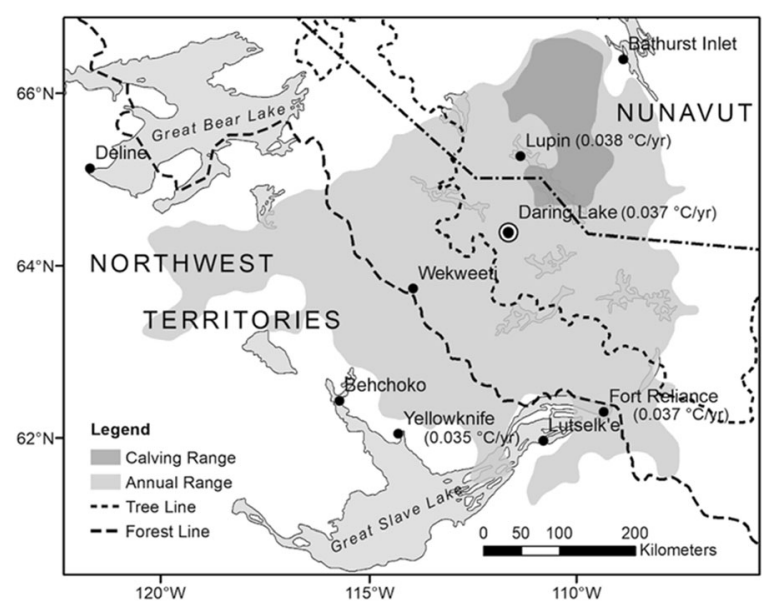

Figure 2. The location of the Daring Lake study area in relationship to the Bathurst caribou herd's annual range and calving area, as inferred from GPS collar locations obtained from 1996-2015 (Government of Northwest Territories 2019). The three closest Environment and Climate Change Canada (ECCC) meteorological stations are located at Yellowknife, Lupin, and Fort Reliance. Data beside each station name, as well as for Daring Lake, indicate the annual linear increase in temperature since 1950, as interpolated from the CRU v.4.3 database (Harris and others 2014). Strongly positive correlations exist between instrumental temperature records at each station and the CRU data (see Methods text). 
$p<0.001)$, Fort Reliance $(r=0.993, p<0.001)$, and Lupin $(r=0.999, p<0.001$; locations indicated in Figure 2) where much longer instrumental records are available (1943-2018, 1949-2018, and 19592018 , respectively). Based on these strong correlations, there is no reason to expect that the area around Daring Lake would have exhibited different trends prior to the instrumental data collection that began there in 1996. A variety of herbivores occur at the Daring Lake site including red-backed voles (Myodes rutilus), ptarmigan (Lagopus spp.), arctic hares (Lepus arcticus), caribou (Rangifer tarandus), and very occasional moose (Alces alces).

Five distinct habitat-types in which birch occurs were identified in the terrain around Daring Lake (Appendix A.1) based on various factors known to be involved in structuring tundra environments along topographic gradients including snow accumulation patterns, moisture and drainage patterns, wind exposure, and vegetation structure. Two completely separate areas (at least $200 \mathrm{~m}$ apart) of each habitat-type were selected, and a $10 \times 10 \mathrm{~m}$ plot was established in each in 2006 (See photos in Appendix A.2). Four representatives of typical birch plants within each plot were chosen as 'focal' shrubs.

\section{Birch Shrub Cover and Stature Measurements}

Birch cover in each $100 \mathrm{~m}^{2}$ plot was carefully mapped by hand at a scale of 1:50 in 2006 and 2016 by subdividing the plot into $2 \times 2 \mathrm{~m}^{2}$, and sketching the extent of birch areal coverage within each square (using direct measurements of shrub sizes to scale sketches appropriately). Since the data were collected by different (single) researchers in 2006 versus 2016 , the precision of the sketch maps produced from the two sampling years was tested by comparing the direct measurements of the four focal shrubs in each plot (described below) to the map-inferred areal extent of each of these shrubs for each of the sampling years. We found no statistically significant differences in bias between the two researchers' data sets, indicating that the temporal comparison of cover change is robust (see Appendix B for details of comparison). Cover maps were scanned $(\sim 4700 \times 4700$ pixels $)$, and areas of shrub cover filled in with black (Paintbrush 2.1.2) before resolving the pixels to either black or white and determining the \% of the former (using ImageJ $1.50 \mathrm{i})$.

Morphological measurements of each focal birch were made in both 2006 and 2016 as follows: (1) maximum height; (2) canopy areal coverage (that is, shrub horizontal extent as determined by length and orthogonal width dimensions in the ground surface plane, using $x$ and $y$ directions relative to the plot borders); and (3) number and length of primary shoots (defined as those emanating from the central root collar). We calculated 'lateral dimensions average' as the mean of the length and orthogonal width measurements, and 'total primary shoot length' as the summed lengths of all primary shoots on a shrub.

\section{Birch Stem Ring-Width Dendrochronology Measurements}

Utilizing accepted dendrochronological methodology (that is, consistent with that used in similar studies such as Tape and others 2012, and Ropars and Boudreau 2012), stem sections were obtained from the base of the largest central shoot (as close to the ground as possible) of 25 birch shrubs that were located adjacent to each $100 \mathrm{~m}^{2}$ plot. These samples were obtained from distinct individual plants several meters apart that were more than $4 \mathrm{~m}$ from the $100 \mathrm{~m}^{2}$ long-term monitoring plots (to avoid disturbance), and in areas visually matching the selected habitat-type. Larger shrubs with a dominant main stem were sampled preferentially in order to maximize the temporal extent and quality of ring-width series. Stem samples were soaked in water for 18-24 h, after which thin cross sections were obtained with a sliding microtome and stained with toluidine blue to improve ring visibility (Appendix C). Ring-width series along two separate radii for each stem were obtained with MeasureJ2X software (VoorTech Consulting), using a Velmex sliding measurement stage.

Ring-width series were visually cross-dated within habitat-types using index years of particularly high and low growth as references. Crossdating was statistically validated using the software COFECHA (Tree-Ring Lab, Colombia University). Each series was individually detrended with the program ARSTAN (Tree-Ring Lab, Colombia University) using either a negative-exponential curve or linear regression line (Dearborn and Danby 2018). Ring-width series from 7-9 shrubs in each habitat-type were selected as the most confidently cross-dated, and then averaged to yield master chronologies for each habitat-type. Series that were confidently cross-dated, but that were not well correlated with other series from the same habitat-type were not included in the master chronology for each habitat-type. 


\section{Habitat-type Environmental Characteristics}

Soil moisture was measured on three evenly separated dates between early-July and mid-August using a handheld meter (CS616, Campbell Scientific) with the probes inserted vertically to their full extent (that is, integrating from $0-12 \mathrm{~cm}$ soil depth), or where soils were thinner, at an angle to ensure the probes were completely immersed. Data are reported here as means of four measurements taken at random locations within about $20 \mathrm{~cm}$ of the root collar of each focal shrub.

Soil nutrient availability $\left(\mathrm{NH}_{4}{ }^{+}, \mathrm{NO}_{3}{ }^{-}\right.$, and $\left.\mathrm{PO}_{4}{ }^{-}\right)$ was measured in each plot using Ion Exchange Membranes (IEMs) using a protocol adapted from Giblin and others, 1994-(See Appendix D for full details). Briefly, $5 \times 5 \mathrm{~cm}$ sheets of the cation and anion material (GE Power and Water: CR67HMR and AR204SZRA) were charged in $0.5 \mathrm{M} \mathrm{HCl}$ and $0.5 \mathrm{M} \mathrm{NaHCO}_{3}$, respectively. Two IEMs of each ion type were inserted about $2-3 \mathrm{~cm}$ below the soil surface at random locations within about $20 \mathrm{~cm}$ of the root collar of each focal shrub, and left in situ for 32 days (July 14-August 15), after which they were removed, rinsed with distilled water, and refrigerated. IEMs were eluted in a $2 \mathrm{M} \mathrm{NaCl}+$ $0.1 \mathrm{M} \mathrm{HCl}$ solution (Appendix D), and eluent nutrient concentrations were determined colorimetrically using automated flow analyses (BranLeubbe AutoAnalyzer III, Germany). Recent replicated membrane incubation tests in our laboratory using a range of standard solution concentrations for each nutrient and the elution procedure described above, indicated that these membranes can detect $\mathrm{NH}_{4}-\mathrm{N}$ fluxes above $0.25 \mu \mathrm{g} / \mathrm{cm}^{2}$, and $\mathrm{NO}_{3}-$ $\mathrm{N}$ and $\mathrm{PO}_{4}-\mathrm{P}$ fluxes above $0.05 \mu \mathrm{g} / \mathrm{cm}^{2}$ with an accuracy of $\pm 20 \%$ (Gu and Grogan, unpublished data). These minimum detection limits for ammonium and phosphate were well below the actual amounts accumulated on the majority of field-incubated IEMs, but not for nitrate which hence is excluded from the results reported below.

Active layer depth (ALD) at each focal shrub was estimated by measuring ALD with a metal probe at the nearest plot corner in late August. Snow depth (minimum peak winter value) was estimated at each shrub using either: (1) previous field measurements (Tussock/Sedge habitat-types); (2) photographs and previous observations where appropriate (Esker Plains habitat-type); or (3) by directly measuring the topographic depression at each shrub relative to a nearby raised topographic feature (Watercourse/Snowpack habitat-types) (Appendix E).
Occasional malfunctions on the main TERS climate station resulted in some missing data for snowmelt dates since 2004, and for 2012 air temperatures, and so complementary data were obtained from additional Daring Lake climate stations (Lafleur and Humphreys, unpublished data).

\section{Statistical Analyses}

Shrub stature and environmental variables at each focal shrub were assumed to be independent of each other and so were treated as replicate units $(n=8)$ for computing habitat-type means and standard errors. Significant changes over time in shrub stature variables within each habitat-type were identified using one-sample t tests that compared the decadal changes for individual shrubs against a null mean of 0 . Differences in net shrub growth and in environmental variables among habitat-types were investigated with nested ANOVAs, using a mixed-effect model with habitat-type as a fixed effect and plot as a random effect with focal shrub nested within plot, followed by Tukey means comparison. These analyses were performed in $R$ using the package lme4 (Bates and others 2015). Correlations between variables were computed using Pearson's product-moment linear correlation coefficient. Both the ammonium and phosphate flux data had strongly right-skewed distributions, and the ammonium data, in particular, had many zero (that is, below detection limit) values (15 out of 40). However, natural log transformations of either data set did not substantially alter the overall patterns of statistical results obtained with untransformed data, and so the latter were used in all analyses.

Pearson's product-moment linear correlations were used to relate the master ring-width chronologies for each habitat-type to various annual meteorological variables. To compare variability in shrub growth among habitat-types, we calculated the standard deviation in annual ringwidth for each detrended series and then calculated an average standard deviation for each habitattype.

All climate analyses reported are based on either monthly or annual values for each year from 19962016, and monthly anomalies were calculated as the difference between the monthly variable and its 20-year average. Climate trends over time were tested by computing Pearson's product-moment linear correlation coefficient. 


\section{Results}

\section{Birch Plot Cover and Focal Shrub Stature}

Birch cover increased in 9 of the 10 plots between 2006 and 2016 (Table 1), and there was a signifi- cant absolute increase in average total groundcover across the landscape from 28 to $32 \%$ (Paired $t$ test: $\left.t_{1,9}=2.73, P<0.023\right)$. This small overall increase masks strong spatial heterogeneity in growth responses among the duplicate plots and among

Table 1. Birch Groundcover (\%) in Each of the Duplicate $100 \mathrm{~m}^{2}$ Plots Within the Five Major Shrub Habitat-Types in the Daring Lake Landscape in 2006 and 2016, and Its Absolute and Relative (that is, \% Cover Change Divided by Initial \% Cover to Account for Differences in Initial 2006 Cover) Increases Over that Decade

\begin{tabular}{|c|c|c|c|c|c|}
\hline \multirow[t]{2}{*}{ Habitat-type } & \multirow[t]{2}{*}{ Duplicate plot\# } & \multicolumn{2}{|c|}{ Birch groundcover $(\%)$} & \multirow{2}{*}{$\begin{array}{l}\text { Absolute change } \\
\text { in } \% \text { cover }\end{array}$} & \multirow{2}{*}{$\begin{array}{l}\text { Relative change } \\
\text { in cover }(\%)\end{array}$} \\
\hline & & 2006 & 2016 & & \\
\hline \multirow[t]{2}{*}{ Esker plain } & 1 & 24 & 32 & 8 & 31 \\
\hline & 2 & 17 & 25 & 8 & 46 \\
\hline \multirow[t]{2}{*}{ Sedge } & 1 & 5 & 8 & 3 & 52 \\
\hline & 2 & 9 & 20 & 11 & 115 \\
\hline \multirow[t]{2}{*}{ Snowpack } & 1 & 46 & 47 & 1 & 2 \\
\hline & 2 & 54 & 58 & 3 & 6 \\
\hline \multirow[t]{2}{*}{ Tussock } & 1 & 13 & 7 & -6 & -47 \\
\hline & 2 & 13 & 13 & 1 & 3 \\
\hline \multirow[t]{2}{*}{ Watercourse } & 1 & 34 & 40 & 6 & 18 \\
\hline & 2 & 62 & 72 & 11 & 17 \\
\hline Overall mean & & $28(6.4)$ & $32(7.0)$ & 4 & 24 \\
\hline
\end{tabular}

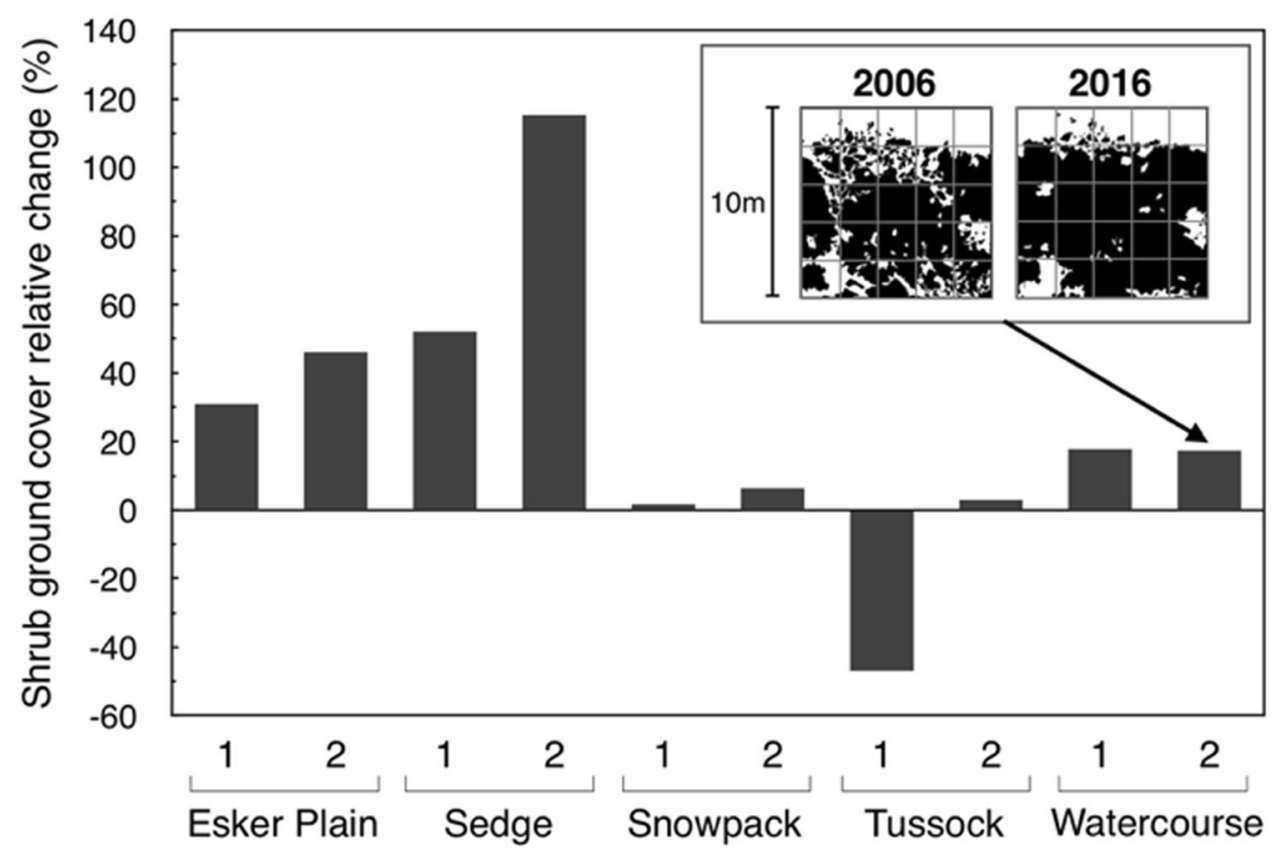

Figure 3. Birch shrub cover relative change from 2006 to 2016 (that is, change in cover relative to initial 2006 cover) in each of the duplicate long-term monitoring $100 \mathrm{~m}^{2}$ plots for each of the five major habitat-types in the Daring Lake low arctic tundra landscape. The inset diagram illustrates an example (for the Watercourse habitat-type second plot) of the actual cover data in the two sampling years that were used to compute the relative cover change. 

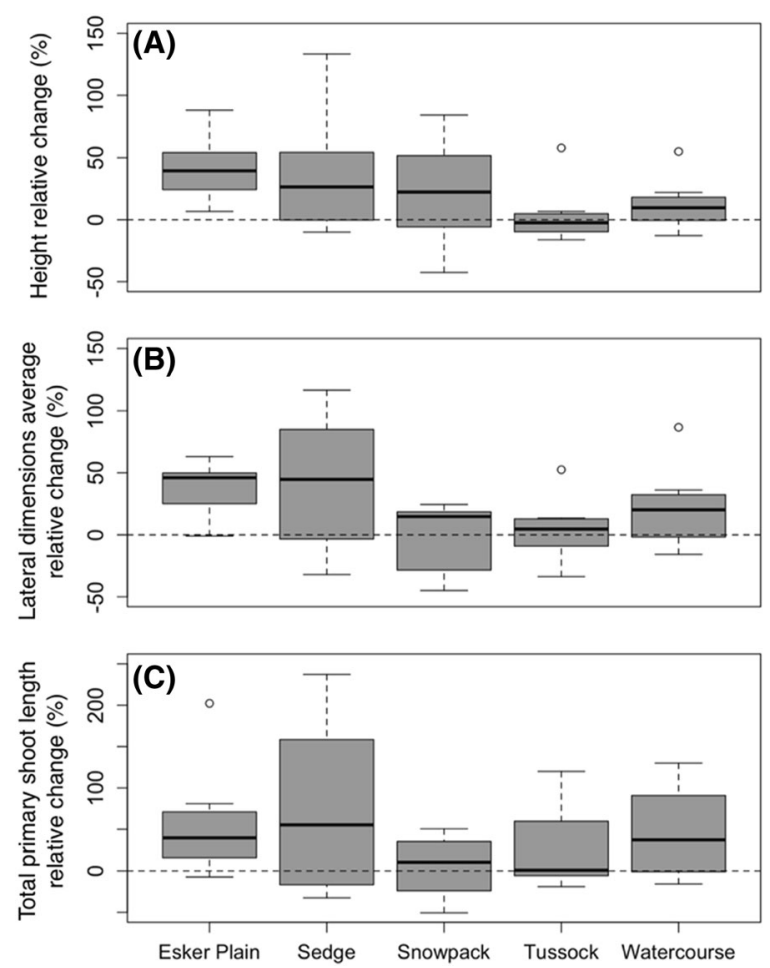

Figure 4. Mean relative changes in birch shrub height $\mathbf{A}$, lateral dimensions average $\mathbf{B}$ and total primary shoot length $\mathbf{C}$ for the four focal shrubs in the duplicate plots of each habitat-type over the 2006-2016 decade (that is, change is computed relative to initial 2006 values; $n=8$ ). Note the scale differences in the $\mathrm{Y}$ axes. Bolded lines indicate the median; boxes and whiskers represent the 25 th and 75 th, and 0 th and 100th percentiles, respectively (excluding outliers). White dots indicate outliers, which are defined as values more than 1.5 times the interquartile range either below the 25 th or above the 75th quartiles.

habitat-types. Furthermore, the extent of initial (2006) cover differed greatly among habitat-types and plots (Table 1). Accordingly, the relative cover changes (that is, \% cover change divided by initial $\%$ cover) were large and highly variable compared to the absolute increases, with the mean birch cover increase relative to 2006 cover averaging $24 \%$ across all plots, and ranging from 115 to $-47 \%$ (Figure 3, Table 1). Finally, although birch cover was generally most extensive in the Watercourse and Snowpack habitat-types, the largest relative increases were in the Esker Plain and Sedge habitat-types, which are located in the driest and wettest topographic parts of the landscape, respectively (Figure 3, Appendix A.1).

The detailed morphological measurements of the individual focal shrubs in each plot also indicated substantially enhanced growth. Mean height in
2016 relative to 2006 increased by $23 \%$ on average $(t=4.20, P<0.001)$, and these increases varied from 3 to $41 \%$ among the habitat-types (Figure 4, Table 2). However, there was strong variability in height change among individual shrubs within each habitat-type (see Figure 4 data distributions; and Table 2 standard errors of the relative increases-which are based on paired measures of the same shrub over time and were often large enough to exceed half the mean relative change), resulting in no overall statistically significant differences among habitat-types (or plots). Likewise, the lateral dimensions average (that is, the average of canopy areal length and width) increased on average by $25 \%$ relative to 2006 values $(t=3.06, P$ $<0.004)$, and these increases varied from -1 to $60 \%$ among the habitat-types (Table 2), but again strong variability among individual shrubs precluded statistically significant differences among habitat-types (or plots). Furthermore, and consistently matching the growth responses reported above, mean total primary shoot length increased by $42 \%$ relative to 2006 values $(t=3.90, P<0.001)$, and these increases varied from 5 to $75 \%$ among the habitat-types (Table 2), but once again strong variability among individual shrubs (Figure 4, Table 2) precluded statistically significant differences among habitat-types (or plots).

Overall, these plot cover and focal shrub datasets, representing two distinct metrics at two different spatial scales, were remarkably consistent in indicating not just statistically significant but also similar magnitude increases in birch relative growth over the decade since 2006. Further evidence of this profound consistency is the significant and strong correlations between the relative cover changes in each plot over the decade and the plot averages of relative change in each of the focal shrub stature metrics (Figure 5; $R^{2}$ values indicate $50-80 \%$ of the total variation explained).

\section{Birch Shrub Dendrochronology}

The master ring-width index chronologies for the five habitat-types spanned from 30 to 58 years (Figure 6). Although we sampled 25 birch shrubs per habitat-type, only 7-9 of them could be confidently cross-dated because of inconsistencies in growth patterns between individual shrubs within plots. The resulting master chronologies for each habitat-type were highly variable, with no visible patterns of shared synchronous peaks or troughs (Figure 6; see for example habitat-type variation for 2004 which was a relatively cool year, and 2006 and 2012, both of which were relatively warm 
Table 2. Mean Height, Lateral Dimensions Average, and Total Primary Shoot Length for the Eight Focal Birch Shrubs in the Duplicate Plots of the Five Major Habitat types Within the Daring Lake Landscape in 2006 and 2016, and Their Absolute and Relative (that is, Accounting for Differences in Initial 2006 Values) Increases Over that Decade

\begin{tabular}{|c|c|c|c|c|c|c|c|c|c|c|c|c|}
\hline \multirow[t]{2}{*}{ Habitat type } & \multicolumn{4}{|c|}{ Height } & \multicolumn{4}{|c|}{ Lateral dimensions average } & \multicolumn{4}{|c|}{ Total primary shoot length } \\
\hline & $\begin{array}{l}2006 \\
(\mathrm{~cm})\end{array}$ & $\begin{array}{l}2016 \\
(\mathrm{~cm})\end{array}$ & $\begin{array}{l}\text { Absolute } \\
\text { increase } \\
(\mathrm{cm})\end{array}$ & $\begin{array}{l}\text { Relative } \\
\text { increase } \\
(\%)\end{array}$ & $\begin{array}{l}2006 \\
(\mathrm{~cm})\end{array}$ & $\begin{array}{l}2016 \\
(\mathrm{~cm})\end{array}$ & $\begin{array}{l}\text { Absolute } \\
\text { increase } \\
(\mathrm{cm})\end{array}$ & $\begin{array}{l}\text { Relative } \\
\text { increase } \\
(\%)\end{array}$ & $\begin{array}{l}2006 \\
(\mathrm{~cm})\end{array}$ & $\begin{array}{l}2016 \\
(\mathrm{~cm})\end{array}$ & $\begin{array}{l}\text { Absolute } \\
\text { increase } \\
(\mathrm{cm})\end{array}$ & $\begin{array}{l}\text { Relative } \\
\text { increase } \\
(\%)\end{array}$ \\
\hline Esker plain & $\begin{array}{l}30 \\
(4.4)\end{array}$ & $\begin{array}{l}42 \\
(5.5)\end{array}$ & $\begin{array}{l}12 \\
(2.5)\end{array}$ & $\begin{array}{l}41 \\
(9.0)\end{array}$ & $\begin{array}{l}75 \\
(10)\end{array}$ & $\begin{array}{l}97 \\
(10)\end{array}$ & $\begin{array}{l}22 \\
(4.9)\end{array}$ & $\begin{array}{l}38 \\
(7.7)\end{array}$ & $\begin{array}{l}340 \\
(86)\end{array}$ & $\begin{array}{l}450 \\
(74)\end{array}$ & $\begin{array}{l}110 \\
(40)\end{array}$ & $\begin{array}{l}56 \\
(23)\end{array}$ \\
\hline Sedge & $\begin{array}{l}31 \\
(4.3)\end{array}$ & $\begin{array}{l}42 \\
(7.1)\end{array}$ & $\begin{array}{l}11 \\
(4.1)\end{array}$ & $\begin{array}{l}36 \\
(17)\end{array}$ & $\begin{array}{l}33 \\
(6.4)\end{array}$ & $\begin{array}{l}48 \\
(12)\end{array}$ & $\begin{array}{l}15 \\
(8.2)\end{array}$ & $\begin{array}{l}60 \\
(32)\end{array}$ & $\begin{array}{l}120 \\
(25)\end{array}$ & $\begin{array}{l}170 \\
(28)\end{array}$ & $\begin{array}{l}57 \\
(31)\end{array}$ & $\begin{array}{l}75 \\
(37)\end{array}$ \\
\hline Snowpack & $\begin{array}{l}43 \\
(5.7)\end{array}$ & $\begin{array}{l}50 \\
(7.2)\end{array}$ & $\begin{array}{l}7 \\
(4.7)\end{array}$ & $\begin{array}{l}22 \\
(15)\end{array}$ & $\begin{array}{l}82 \\
(14)\end{array}$ & $\begin{array}{l}84 \\
(19)\end{array}$ & $\begin{array}{l}2.5 \\
(7.0)\end{array}$ & $\begin{array}{l}-1.3 \\
(10)\end{array}$ & $\begin{array}{l}550 \\
(160)\end{array}$ & $\begin{array}{l}660 \\
(210)\end{array}$ & $\begin{array}{l}100 \\
(79)\end{array}$ & $\begin{array}{l}5 \\
(14)\end{array}$ \\
\hline Tussock & $\begin{array}{l}28 \\
(3.0)\end{array}$ & $\begin{array}{l}28 \\
(2.6)\end{array}$ & $\begin{array}{l}0 \\
(1.8)\end{array}$ & $\begin{array}{l}3.4 \\
(8.3)\end{array}$ & $\begin{array}{l}32 \\
(5.6)\end{array}$ & $\begin{array}{l}33 \\
(7.2)\end{array}$ & $\begin{array}{l}1.5 \\
(3.5)\end{array}$ & $\begin{array}{l}4.5 \\
(8.8)\end{array}$ & $\begin{array}{l}140 \\
(50)\end{array}$ & $\begin{array}{l}150 \\
(45)\end{array}$ & $\begin{array}{l}7.2 \\
(11)\end{array}$ & $\begin{array}{l}26 \\
(17)\end{array}$ \\
\hline Watercourse & $\begin{array}{l}44 \\
(14)\end{array}$ & $\begin{array}{l}48 \\
(15)\end{array}$ & $\begin{array}{l}3.9 \\
(2.0)\end{array}$ & $\begin{array}{l}12 \\
(7.3)\end{array}$ & $\begin{array}{l}51 \\
(15)\end{array}$ & $\begin{array}{l}56 \\
(15)\end{array}$ & $\begin{array}{l}5.3 \\
(5.2)\end{array}$ & $\begin{array}{l}22 \\
(11)\end{array}$ & $\begin{array}{l}170 \\
(51)\end{array}$ & $\begin{array}{l}200 \\
(51)\end{array}$ & $\begin{array}{l}34 \\
(16)\end{array}$ & $\begin{array}{l}46 \\
(19)\end{array}$ \\
\hline Overall mean & & & & 23 & & & & 25 & & & & 42 \\
\hline
\end{tabular}
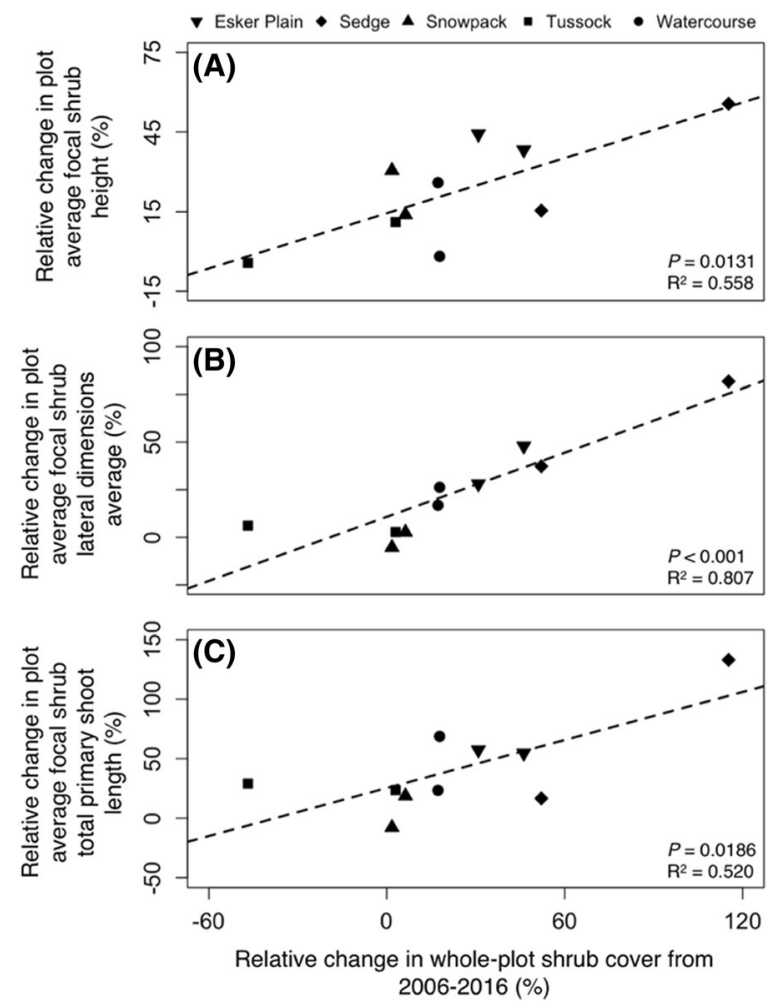

Figure 5. Relative changes in birch cover in each of the ten $100 \mathrm{~m}^{2}$ plots over the 2006-2016 decade in relation to the relative change over that same period in plot-averaged focal birch shrub $(n=4)$ height $\mathbf{A}$, lateral dimensions average $\mathbf{B}$, and total primary shoot length $\mathbf{C}$. Note the scale differences in the $\mathrm{Y}$ axes. years; full climate data are reported below). Annual ring-width indices were not significantly correlated between any two habitat-type chronologies, and there were no significant temporal trends in any habitat-type chronology (Figure 6). Finally, we tested for relationships between each of 45 different climate variables (for example, monthly averages of daily mean and maximum air temperatures, growing degree days, and so on) and each habitattype chronology (225 tests in total), and found no more statistically significant correlations than would be expected by chance.

\section{Soil Environmental Characteristics of the Habitat-types}

Mean summer soil moisture at the base of the focal birch shrubs was significantly wetter in the Sedge and Tussock habitat-types $\left(F_{(4,5)}=8.42, P=0.019\right.$; Figure 7), both of which are located in low-lying areas (Appendix A.1). By contrast, the Snowpack and Watercourse habitat-type soils were on average more than three times drier, and the Esker Plain more than seven times drier (Figure 7).

Mid-summer ammonium and phosphate fluxes in the focal shrub soils were highly variable and did not differ statistically among habitat-types (Figure 7). Nevertheless, at the scale of the individual plants, the relative increases in birch height, lateral dimensions average, and total primary shoot length over the decade from 2006 were significantly or 


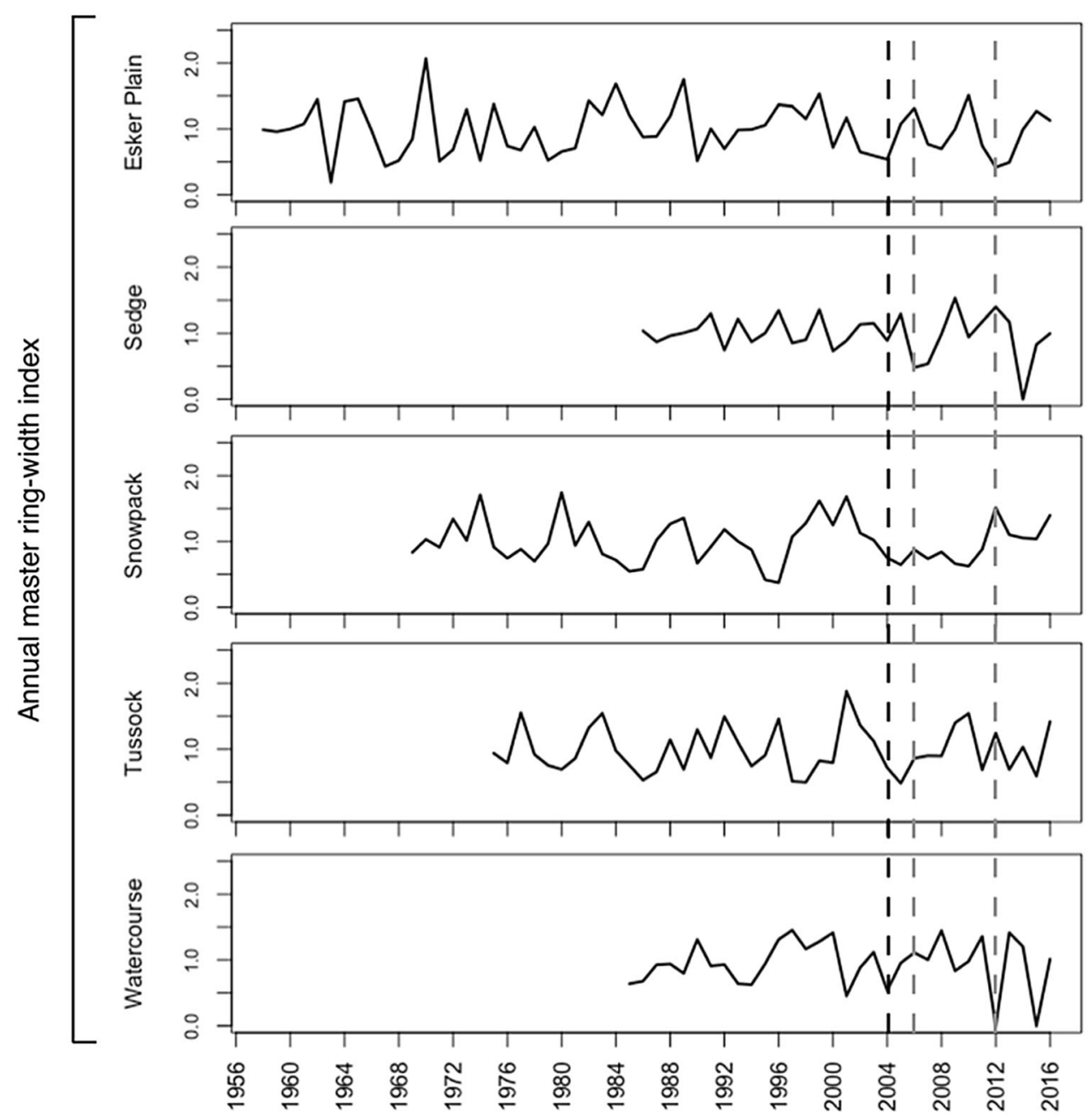

Figure 6. Master annual birch stem ring-width index chronologies for each habitat-type. Data are based on those 7-9 shrubs that were most confidently cross-dated (see Methods) from the 25 oldest/largest shrubs sampled adjacent to the outside perimeter of the duplicate long-term monitoring plots of each habitat-type. The 2004 (black), 2006 and 2012 (both gray) dashed lines highlight relatively cool, and warm years, respectively (see climate data Figure 8).

nearly significantly $(P<0.081$ for primary shoot length) correlated with the soil ammonium fluxes beneath those plants (Appendix F). By contrast, although there were no significant corresponding effects for the soil phosphate fluxes, the latter were significantly correlated with the actual 2016 values for individual shrub height and lateral dimensions average (Appendix G). Soil ammonium flux was also significantly correlated with the actual 2016 values of shrub height (Appendix G). Finally, at the whole plot scale, the relative increases in birch cover were significantly and strongly correlated with plot-averaged soil ammonium flux (explaining $48 \%$ of the total variation), but not phosphate flux or soil moisture (Appendix H).

\section{Climate}

The monthly averages of daily mean air temperatures over the entire Daring Lake climate record (1996-2016) increased significantly for June (by $\sim 1.5^{\circ} \mathrm{C}$ per decade relative to the 20 year mean), and there was a corresponding statistical trend $(P<$ 0.094) for August, but no trends in any other month (Figure 8; Appendix I.1). Growing degree days (GDD) up to July 1 of each year increased over the 20-year period, but there was no significant trend in total annual GDD (Figure 8). Consistent with the air temperature pattern, monthly averages of June daily mean soil temperatures at $0,5,10,20$ and $40 \mathrm{~cm}$ all exhibited similar and statistically significant rates of warming, but there were no 

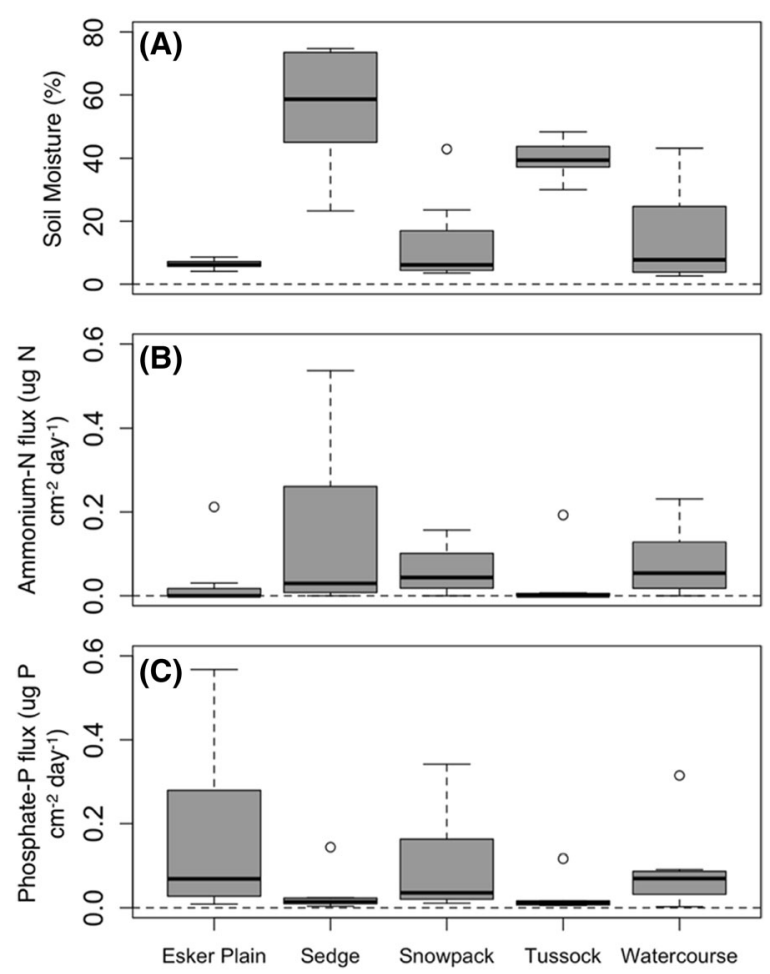

Figure 7. Mean soil moisture $\mathbf{A}$, and ammonium and phosphate fluxes $\mathbf{B}, \mathbf{C}$ beneath the focal birch shrubs in the duplicate plots of the five major birch habitat-types in the Daring Lake landscape in July-August $(n=8$; see Figure 4 for explanation of boxplot format). Soil moisture (volumetric water content \%) was measured at the base of each shrub (to $12 \mathrm{~cm}$ soil depth) three times from early-July to mid-August and averaged for the data presented here. Soil nutrient fluxes were measured by incubating ion exchange membranes from mid-July to mid-August (see Methods for details).

corresponding trends in any other month (Appendix I.2). The monthly maxima of daily mean air temperatures in May and June both increased over the 20 years, but not in any other months (Appendix I.3), and furthermore, the number of days when daily maximum air temperature exceeded $20^{\circ} \mathrm{C}$ in June significantly increased, but not in July or August, or annually (Appendix I.4). Finally, neither monthly nor annual rainfall, nor snowmelt date, exhibited significant 20-year trends (Appendix I.5).

Because the overall conclusion above of a very limited climate warming trend is based on data from just one climate station, we evaluated the accuracy of the Daring Lake data in the context of the three nearest Environment Canada long-term climate stations (See Methods; Figure 2). Data from two gridded climate datasets (CRU TS3.10, Harris et al. 2014 and DAYMET v.3, Thornton and others
2018) were compared to the monthly instrumental records from the four stations. The temperature data for each station including Daring Lake correlated strongly and positively with the corresponding grid cell data $(r>0.995$ and $P<0.001$ for all relationships). Due to varied lengths of instrumental record, as well as periods of missing instrumental data, we used the CRU data to calculate long-term temperature change trends (1950-2018) for each of the four locations. We also calculated trends from 1996-2016, which includes the period of observation reported in this study as well as the decade prior. In summary, these analyses indicated that the entire region experienced a significant linear warming trend since $1950(P<$ 0.001 ; Figure 2) of $0.034-0.038^{\circ} \mathrm{C} / \mathrm{y}$ (a similar rate to most of the Northern hemisphere over the same period-IPCC, 2013), with winter warming being nearly three times the rate of summer. However, most importantly in the context of our study here, there were no significant trends at any of the four sites in either annual or winter temperatures for the period 1996-2016.

\section{Discussion}

Birch Shrub Net Growth in the Daring Lake Landscape Between 2006 and 2016

Our results clearly demonstrate substantial net growth and areal expansion of birch shrubs in the Daring Lake landscape over the decade since 2006. In answer to the first part of our Question \#1, birch shrub cover across the landscape's diverse habitattypes increased on average from $28 \%$ of total groundcover in 2006 to $32 \%$ in 2016, and increases relative to initial 2006 cover averaged $24 \%$. Our repeat measurements of individual birch shrubs also indicated relative increases in height, canopy areal extent, and total primary shoot length of the same general magnitude as for overall cover. Despite substantial variability in birch cover change among plots, and in growth responses of individual shrubs, these two essentially independent datasets-measured at two different spatial scales-were remarkably consistent. First, all of the diverse metrics that we measured indicated statistically significant absolute increases over the decade, and furthermore, the relative increases in these metrics (that is, changes relative to initial 2006 values) were all of generally similar magnitude (Tables 1, 2). Second, the pattern of birch cover relative change at the whole $100 \mathrm{~m}^{2}$ plot scale, was closely and significantly correlated with the plot-averaged relative changes in focal shrub 

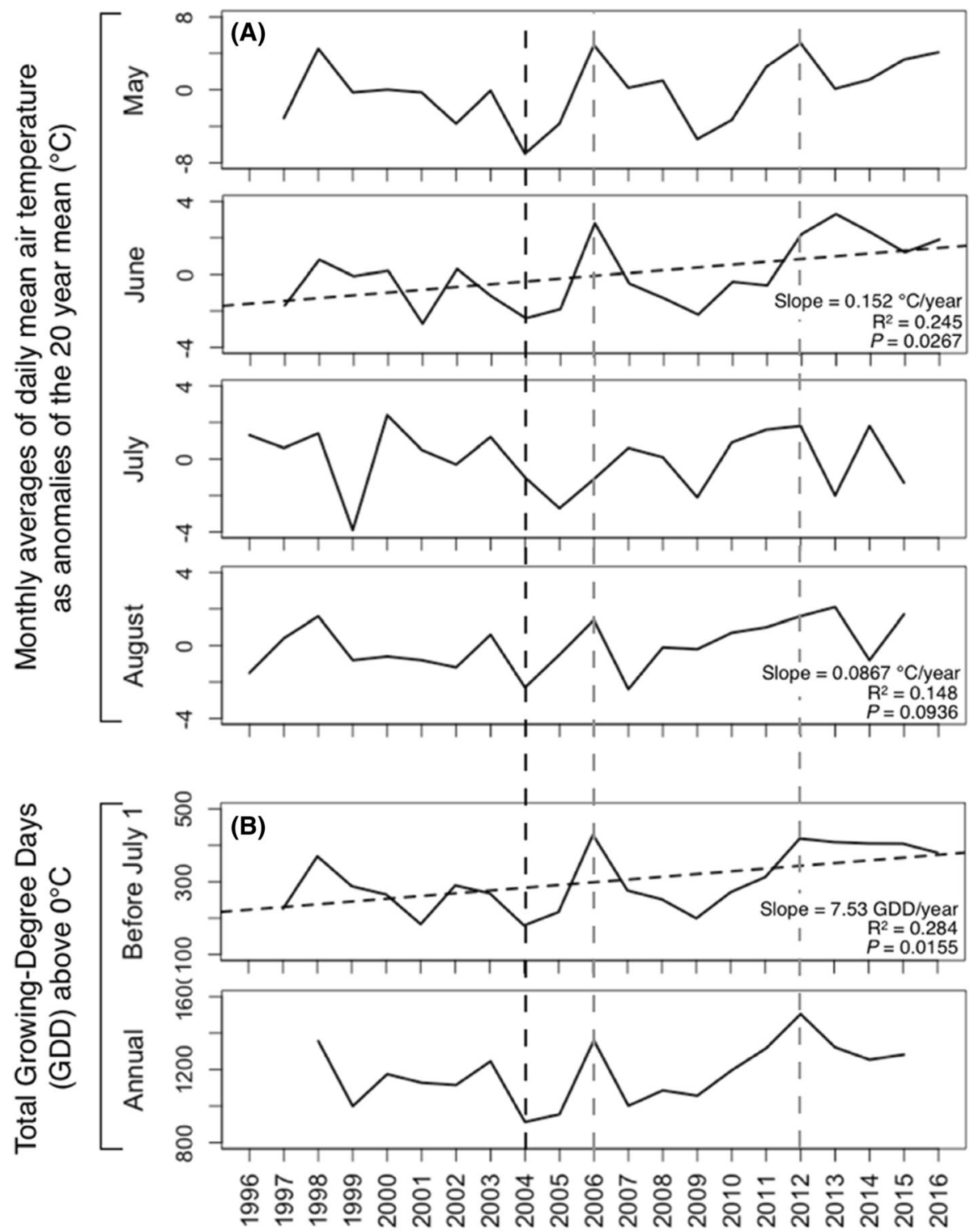

Figure 8. Daring Lake monthly averages of daily mean air temperature as anomalies of the 20 year means for each month from May-August 1996-2016 A, and total growing degree days for the periods up to July lst each year and for the full year B. Linear regression lines are shown where a statistically significant trend over the 20-year time period was observed. The 2004 (black), 2006 and 2012 (both gray) dashed lines highlight relatively cool, and warm years, respectively.

height, lateral dimensions average, and total primary shoot length (Figure 5). Third, all measures of relative increase at both spatial scales were greatest in the Esker Plain and Sedge habitat-types (Figure 3, Table 1).

However, in answer to the second part of Question \#1, although there was a consistent pattern of environmental differences among habitat-types at the two spatial scales, our statistical analyses of the focal shrub data $(n=8)$ provided no evidence that habitat-type was a significant determinant of birch growth responses across the landscape. These findings align with preliminary analysis of several repeat photographs of the Daring Lake landscape (2004 and 2016) that clearly indicate some patches within a variety of habitat-types where birch shrub size and extent have substantially increased, and many other patches where there has been no observable change (Appendix J).

\section{What Factors Might Explain Birch Net Growth and Areal Expansion?}

Below, we apply our conceptual framework (Figure 1) of the various potential explanatory factors and their principal interactions that may drive 
decadal patterns of deciduous shrub growth and expansion across low Arctic landscapes specifically to the pattern of results from the Daring Lake habitat-types.

\section{Climate Change as a Factor Driving Net Growth}

Many studies documenting recent net growth and areal expansion of deciduous shrubs across the Arctic tundra have significantly correlated those increases with warming climate (Forbes and others 2010; Blok and others 2011; Ropars and Boudreau 2012; Tape and others 2012). Furthermore, experimental warming with plastic greenhouses at Daring Lake (that raised mean air and soil temperatures across all summer months by $\sim 2.2^{\circ} \mathrm{C}$ ) doubled birch shoot biomass (Zamin and Grogan 2012), indicating that this species has the potential at our site to respond to strong prolonged growing season temperature increases. However, the 20year Daring Lake climate station records provide only limited evidence of climate warming. Note that one of the rationales for our analysis of climate trends over the 20 -year period starting a full decade prior to the onset of our shrub measurements is that warming can stimulate birch shrub growth even over a subsequent colder period (Kaarlejärvi and others 2015). Significant warming trends occurred only in the early growing season, and were of relatively small magnitude compared to many other, mostly more coastal, locations/shrub study sites. For example, we found a $0.15^{\circ} \mathrm{C}$ per year warming trend but only for the month of June. That trend averaged across the full year is equivalent to about $1 / 5$ th of the mean annual temperature increase across the entire Arctic over recent decades (Comiso and Hall 2014; IPCC 2013).

The absence of a significant influence of habitattype in our data also suggests that climate change may not have been the primary driving mechanism for the growth increases we observed at Daring Lake. Habitat-type effects are to be expected if growth increases were being largely determined by changes in a single common factor (for example, warming) because one would expect deciduous shrubs within more fertile habitat-types across the landscape to display a combination of greater net growth, greater sensitivity of growth to annual climate, and stronger correlation of annual growth trends between shrubs (that is, more synchronous growth patterns), as compared to shrubs in less fertile habitats. In northern Alaska, shrubs in more favorable habitattypes tended to respond more strongly not just to multi-year warming trends, but also to interannual temperature variations (Tape and others 2012). In northern Quebec, dwarf birch (Betula glandulosa) expanded in both terrace and hilltop habitat-types since the late 1950s, but the increase was nearly twice as large on terraces (Ropars and Boudreau 2012). Shrub expansion near treeline in Siberia differed significantly among habitat-types and was largest in upland areas where permafrost-thawing processes were prevalent (Frost and Epstein 2014). However, all three of the above studies documenting differences in shrub growth among habitat-types were based in sites that have experienced substantial warming and warming-related interactive effects (for example, permafrost degradation). By reverse logic, the absence of a significant habitat-type effect at Daring Lake is consistent with our conclusion that climate warming was not the primary determinant of the pattern of birch net growth that we observed.

Our dendrochronological data also support the conclusion that the observed shrub growth patterns were not due to climate warming. If the temperature had been a primary determinant of growth, one would expect to see annual growth patterns that are shared among shrubs (at least within a habitat-type) and correlated with annual climate trends. However, in answer to our Question \#2, we found very few common growth signals among shrubs, as indicated by the lack of correlation among ring-width chronologies between habitattypes, as well as among individual shrubs within each habitat-type (only $\sim 1 / 3$ of the samples could be confidently cross-dated). Furthermore, none of the ring-width chronologies in any habitat-type were significantly correlated with climate.

This lack of a shared climate signal in the shrub secondary growth data-a signal which has previously been clearly documented in Betula (Blok and others 2011; Ropars and others 2015, 2017; Trudel and Lévesque unpubl. data) -may be due to several factors. Daring Lake is far from B. glandulosa's northern range limit (CAVM 2003), so it is possible that shrub growth at this relatively southerly site is less temperature-limited. In addition, our dendrochronologies were based on stem samples, and although some previous tundra studies have significantly correlated stem ring-width chronologies to climate warming trends (Ackerman and others 2017; Tape and others 2012; Forbes and others 2010), it is now known that birch root collars provide much more climate-sensitive data than stems (Ropars and others 2017). 


\section{Recovery Following Disturbance as a Factor Driving Net Growth}

Net growth may occur as vegetation is recovering or responding to earlier disturbance events such as instances of permafrost thaw, soil active layer detachments, palsa subterranean ice accumulation/ thaw cycles, fire, disease and insect outbreaks, and extreme climatic episodes. Such disturbances are naturally occurring discrete events that contribute to the long-term temporal dynamics of growth mortality equilibrium in tundra plant populations. However, there have been no significant fires, herbivorous insect outbreaks, or periods of unusually high birch mortality in Daring Lake area in recent decades (Joachim Obst (long-term TERS researcher/naturalist), personal comm.), and the site's climate record contained no evidence for any prolonged period of drought or set of unusually severe winters in the past 20 years. Finally, there were no prolonged, collective periods of lower or higher growth visible in the ring-width chronologies which extend back approximately 40 years. Accordingly, we conclude that it is highly unlikely that the growth patterns observed are a recovery response to some previous disturbance event.

\section{Declining Caribou Herbivore Impacts as a Factor Driving Net Growth}

Caribou are an important herbivore in the central low Arctic, and Daring Lake lies in the middle of the Bathurst caribou herd's summer range (Adamczewski and others 2019; Figure 2). Deciduous shrubs seem to constitute about $45 \%$ of caribou spring and summer diets in North America, although studies are scarce and the proportion of birch compared to willow (Salix spp.) is undetermined (see recent review of dietary composition studies in Appendix A of Zamin and others 2017), but probably quite low (Obst, Adamczewski, and Côté, pers. comm.). Nevertheless, focused studies in northern Quebec indicate that birch is a substantial proportion of the summer diet of caribou (Crête and others 1990), and that caribou herbivory can significantly reduce birch biomass and productivity in their summer ranges there (Manseau and others 1996). Furthermore, a large-scale remote sensing study that incorporated extensive on-the-ground quantification of birch (and willow) browsing damage in Nunavik concluded that intense caribou herbivory had prevented net increases in shrub cover over the past 40 years, even though there had been rapid climate warming in that region over that period (Plante and others 2014). At Daring Lake, Zamin and Grogan (2013) found that caribou exclusion from about $400 \mathrm{~m}^{2}$ plots for 5 years (between 2004 and 2009) resulted in a doubling of birch leaf biomass, and similar results have been reported from experimental reindeer exclosures in N. Sweden (Olofsson and others 2009). Together, these results strongly suggest that herbivory and trampling by caribou-especially when they are in high numbers-can be an important constraint on low Arctic tundra birch growth. However, like most other major N. American caribou herds (Fauchald and others 2017), the Bathurst herd has declined severely in recent decades, from an estimated 470,000 in 1986 to 32,000 in 2009 and most recently to 8200 in 2018 (Adamczewski and others 2019). Effects of this particular caribou herd decline are visibly apparent at Daring Lake-for instance, our repeat photography clearly illustrates birch shrub expansion within some landscape patches and also some recent birch encroachment across caribou trail pathways (Appendix J).

We conclude that the release from these herbivory and trampling pressures due to the severe ongoing reduction in the Bathurst caribou herd is the most likely explanation for the net growth and expansion of birch we observed over the 20062016 decade. First, caribou are probably the principal birch herbivore in this low arctic landscapearctic hares definitely significantly browse individual birch especially close to the eskers (pers. obs.), but have strong habitat-type preferences. Second, and by contrast, caribou are constantly moving through the entire landscape, and so their herbivory and trampling are likely to be spatially uniform over decadal timescales, thereby affecting birch shrubs in multiple different habitat-types, as has been previously observed in Quebec (Manseau and others 1996).

Why did we not detect an increase in ring-widths following the presumed release from caribou herbivory? Arctic birch stem and root collar ring-width growth can respond to climate warming (for example, Forbes and others 2010; Ropars and others 2015), and it is known that herbivory pressure can significantly influence stem secondary growth rates of other Betula species (Speed and others 2011). One possible explanation is that birch shrubs have a relatively strong ability to quickly divert resources to the conversion of short lateral sideshoots to long shoots under favorable conditions such as when soil fertility is enhanced (BretHarte and others 2001), which may result in an increase in apparent stature without substantial thickening of the main axis. However, since warming stimulates both lateral sideshoot growth (Bret-Harte and others 2001) and stem and root 
collar secondary growth (Forbes and others 2010 and Ropars and others 2015, respectively), this explanation requires that there be a substantial allocation difference in birch growth responses to release from herbivory compared to warming. Compensatory growth in the form of rapid extension of lateral short shoots following simulated caribou herbivory has been observed in birch (Champagne and others 2012), supporting the possibility that release from herbivory could have stimulated new lateral shoot production at our site with no major change in main shrub axis thickening rates.

\section{Factors Affecting Individual Shrub Growth Across the Landscape}

Although a release from caribou herbivory and trampling appears to be the principal factor driving the overall net increase in birch shrub stature and cover across the Daring Lake landscape, our soil environmental data indicate that other factors significantly affected the growth rates of individual shrubs. In answer to Question \#3, soil ammonium flux, in particular, was positively correlated with the relative increases in all three stature metrics of individual shrubs (Appendix F), and to the overall relative increases in birch cover in the $100 \mathrm{~m}^{2}$ monitoring plots (Appendix $\mathrm{H}$ ). The consistency of these correlations for all measured variables from two essentially independent datasets at two different spatial scales, at least suggests that increases in soil nitrogen availability may have been a contributory causal factor in determining the birch relative growth responses. In other words, either release from herbivory, and/or June warming, may have enhanced soil nitrogen availability beneath some individual shrubs, resulting in the observed variation in individual birch relative growth responses. By contrast, although there were no significant corresponding effects for the soil phosphate fluxes, the latter were significantly correlated with the 2016 values for birch height and lateral dimensions average (Appendix G). Likewise, the soil ammonium fluxes were significantly correlated with the 2016 birch height values (Appendix G).

Given that experimental factorial fertilizer additions have previously demonstrated that birch shrub growth in at least mesic tussock tundra at our site is strongly co-limited by both nitrogen and phosphorus (Zamin and Grogan 2012; Zamin and others 2014), it is not surprising that in situ soil fluxes of both nutrients should be correlated with birch growth dynamics and stature variables. Perhaps more surprising is that in situ fine-scale vari- ability in these fluxes across the landscape was such an important determinant of those growth responses. Individual shrubs that were even short distances apart (that is, within the same plot) often had very different nutrient flux rates in their underlying soil, and there were no overarching differences in mean soil fertility among habitattypes. Even those habitat-types with the lowest average ammonium fluxes (Esker Plain and Tussock) had occasional shrub locations with relatively high fluxes, and likewise for phosphate (Figure 7). Together, these results imply that the growth rate of an individual shrub following herbivore release is determined more by its precise location on the landscape, and the amount of soil resources available in its immediate surroundings, than the habitat-type that the shrub resides in. This conclusion suggests, therefore, that in contrast to the important influence of habitat-type in predicting shrub growth responses to climate warming (for example, Tape and others 2012; Ropars and others 2015; Blok and others 2015), it has little influence in predicting shrub growth responses to herbivory release. Instead, much finer-scale spatial variability in soil ammonium fluxes seems to determine the relative growth responses of individual shrubs to release from herbivory. Furthermore, likewise, fine-scale spatial variability in both ammonium and phosphate fluxes correlates with the absolute values of birch height across the landscape (and phosphate fluxes also seem to be a strong determinant of shrub lateral dimensions).

\section{Implications}

This study demonstrates substantial net birch growth and cover expansion across the Daring Lake landscape over the 2006-2016 decade, when there was only limited evidence of climate warming but a severe decline in the caribou herd. Although not absolutely conclusive, our study's results suggest the potential for caribou herbivore population declines to significantly contribute to increasing deciduous shrub abundance across the Arctic. If correct, the shifts in vegetation should be strongest in tundra areas with the most drastic declines in caribou populations, and so a quantitative analysis of herd decline rates versus average range satellitebased greening rates across the Arctic would be a fascinating research extension of our study. In terms of future impacts, many caribou populations are declining globally, driven by a number of threats which are likely to worsen as climate change continues (Fauchald and others 2017). Furthermore, an experimental study has already 
demonstrated that birch growth responses to warming can be enhanced by excluding reindeer (Olofsson and others 2009). If deciduous shrub expansion in response to release from caribou herbivory and trampling is widespread, future Arctic vegetation change (and consequently, decreased land surface albedo and greater $\mathrm{CO}_{2}$ release from Arctic soils) will be substantially greater than would be expected from warming alone, particularly in regions where warming is not yet substantial. Finally, in terms of modeling future tundra vegetation change, our results suggest that the significant influence of habitat-type on deciduous shrub expansion in response to climate warming may not apply in predicting shrub change as a result of declining caribou herds.

\section{ACKNOWLEDGEMENTS}

We are indebted to Brian Reid for establishing the birch long-term monitoring plots and collecting the initial 2006 data on birch morphology and areal coverage. We thank Joachim Obst and Jan Adamczewski for insights on the vegetation history and caribou interactions in the study area, and Esther Lévesque, Marilie Trudel, and Qian Gu for their guidance and assistance in implementing the project. We appreciate the help of Katherine Dearborn and Greg King with the dendrochronological analysis, Electra Nicole, Daniel Krivenko, Ki-Youn Kim for assistance in the field, and Yvette Chirinian for completing the lab chemistry analyses. Thank you to Dr. Peter Lafleur and Dr. Elyn Humphreys for kindly providing climate data and advice on its interpretation, and to Karin Clark and the Government of the Northwest Territories' Environment and Natural Resources division for the use of the Tundra Ecosystem Research Center at Daring Lake. We are grateful to the Thich Government for permission to conduct research on their lands. This research was supported by NSERC USRA (RA) and Discovery (PG) grants, and by the Northern Scientific Training Program. Several specific measures were taken by the authors to reduce the environmental impacts of the activities associated with completing the science reported in this study (Appendix K).

\section{OPEN ACCESS}

This article is licensed under a Creative Commons Attribution 4.0 International License, which permits use, sharing, adaptation, distribution and reproduction in any medium or format, as long as you give appropriate credit to the original author(s) and the source, provide a link to the Creative Commons licence, and indicate if changes were made. The images or other third party material in this article are included in the article's Creative Commons licence, unless indicated otherwise in a credit line to the material. If material is not included in the article's Creative Commons licence and your intended use is not permitted by statutory regulation or exceeds the permitted use, you will need to obtain permission directly from the copyright holder. To view a copy of this licence, visit https://creativecommons.org/licenses/by/4.0/.

\section{FUNDING}

Funding was provided by Canadian Foundation for Climate and Atmospheric Sciences, Natural Sciences and Engineering Research Council of Canada (Grant No. 388660), and Polar knowledge Canada's Northern Scientific Training Program.

\section{REFERENCES}

Ackerman D, Griffin D, Hobbie S, Finlay J. 2017. Arctic shrub growth trajectories differ across soil moisture levels. Glob Chang Biol 23:4294-302.

Adamczewski J, Boulanger J, Sayine-Crawford H, Nishi J, Cluff D, Williams J, Le-Clerc L-M. 2019. Estimates of breeding females $\&$ adult herd size and analyses of demographics for the Bathurst herd of barren-ground caribou: 2018 calving ground photographic survey. report 279. Environ Nat Resour, Government of Northwest Territories.

Bates D, Mächler M, Bolker B, Walker S. 2015. fitting linear mixed-effects models using lme4. J Stat Softw 67.

Beck P, Goetz S. 2011. Satellite observations of high northern latitude vegetation productivity changes between 1982 and 2008: ecological variability and regional differences. Environ Res Lett 6:045501.

Björk RG, Klemedtsson L, Molau U, Harndorf J, Ödman A, Giesler R. 2007. Linkages between N turnover and plant community structure in a tundra landscape. Plant Soil 294:247-61.

Blok D, Sass-Klaassen U, Schaepman-Strub G, Heijmans MMPD, Sauren P, Berendse F. 2011. What are the main climate drivers for shrub growth in Northeastern Siberian tundra? Biogeosciences 8:1169-79.

Bonney M, Danby R, Treitz P. 2018. Landscape variability of vegetation change across the forest to tundra transition of central Canada. Remote Sens Environ 217:18-29.

Bråthen KA, Lortie C. 2016. A portfolio effect of shrub canopy height on species richness in both stressful and competitive environments. Funct Ecol 30:60-9.

Bret-Harte MS, Shaver GR, Zoerner JP, Johnstone JF, Wagner JL, Chavez AS, Gunkelman RFIV, Lippert SC, Laundre JA. 2001. Developmental plasticity allows betula nana to dominate tundra subjected to an altered environment. Ecology 82:18-32.

Buckeridge K, Zufelt E, Chu H, Grogan P. 2010. Soil nitrogen cycling rates in low arctic shrub tundra are enhanced by litter feedbacks. Plant Soil 330:407-21. 
Cameron EA, Lantz TC. 2016. Drivers of tall shrub proliferation adjacent to the Dempster Highway, Northwest Territories. Can Environ Res Lett 11:045006.

CAVM. 2003. Circumpolar Arctic Vegetation Map. Alaska: US Fish and Wildlife Service.

Champagne E, Tremblay JP, Côté SD. 2012. Tolerance of an Expanding Subarctic Shrub, Betula glandulosa, to Simulated Caribou Browsing. PLoS ONE 7:1-7.

Chapin FSIII, Sturm M, Serreze M, McFadden J, Key J, Lloyd A, McGuire AD, Rupp TS, Lynch AH, Schimel JP, Beringer J, Chapman WL, Epstein HE, Euskirchen E, Hinzman LD, Jia G, Ping CL, Tape KD, Thompson CDC, Walker DA, Welker J. 2005. Role of land-surface changes in Arctic summer warming. Science 310:657-60.

Chu H, Grogan P. 2010. Soil microbial biomass, nutrient availability and nitrogen mineralization potential among vegetation-types in a low arctic tundra landscape. Plant Soil 329:411-20.

Comiso JC, Hall DK. 2014. Climate trends in the Arctic as observed from space. WIREs Clim Change 5:389-409. https:// doi.org/10.1002/wcc. 277 .

Crête M, Huot J, Gauthier L. 1990. Food selection during early lactation by caribou calving on the tundra in Quebec. Arctic 43:60-5.

Dearborn K, Danby R. 2018. Topographic influences on ring widths of trees and shrubs across alpine treelines in southwest Yukon. Arct Antarct Alp Res 50:e1495445.

DeMarco J, Mack MC, Bret-Harte MS. 2011. The effects of snow, soil microenvironment, and soil organic matter quality on $\mathrm{N}$ availability in three Alaskan Arctic plant communities. Ecosystems 14:804-17.

Elmendorf S, Henry GHR, Hollister RD, Björk RG, Bjorkman AD, Callaghan TV, Collier LS, Cooper EJ, Cornelissen JHC, Day TA, Fosaa AM, Gould WA, Grétarsdóttir J, Harte J, Hermanutz L, Hik DS, Hofgaard A, Jarrad F, Jónsdóttir IS, Keuper F, Klanderud K, Klein JA, Koh S, Kudo G, Lang SI, Loewen V, May JL, Mercado J, Michelsen A, Molau U, Myers-Smith IH, Oberbauer SF, Pieper S, Post E, Rixen C, Robinson CH, Schmidt NM, Shaver GR, Stenström A, Tolvanen A, Totland Ø, Troxler T, Wahren CH, Webber PJ, Welker JM, Wookey PA. 2012a. Global assessment of experimental climate warming on tundra vegetation: heterogeneity over space and time. Ecol Lett 15:164-75.

Elmendorf S, Henry G, Hollister R, Björk R, Boulanger-Lapointe N, Cooper E, Cornelissen J, Day T, Dorrepaal E, Elumeeva T, Gill M, Gould W, Harte J, Hik D, Hofgaard A, Johnson D, Johnstone J, Jónsdóttir I, Jorgenson J, Klanderud K, Klein J, Koh S, Kudo G, Lara M, Lévesque E, Magnússon B, May J, Mercado-Díaz J, Michelsen A, Molau U, Myers-Smith I, Oberbauer S, Onipchenko V, Rixen C, Martin Schmidt N, Shaver G, Spasojevic M, Pórhallsdóttir P, Tolvanen A, Troxler $\mathrm{T}$, Tweedie C, Villareal S, Wahren C, Walker X, Webber P, Welker J, Wipf S. 2012b. Plot-scale evidence of tundra vegetation change and links to recent summer warming. Nat Clim Chang 2:453.

Fauchald P, Park T, Tømmervik H, Myneni R, Hausner V. 2017. Arctic greening from warming promotes declines in caribou populations. Sci Adv 3:e1601365.

Forbes BC, Fauria MM, Zetterberg P. 2010. Russian Arctic warming and 'greening' are closely tracked by tundra shrub willows. Glob Chang Biol 16:1542-54.
Frost G, Epstein H. 2014. Tall shrub and tree expansion in Siberian tundra ecotones since the 1960s. Glob Chang Biol 20:1264-77.

Giblin AE, Nadelhoffer KJ, Shaver GR, Laundre JA, McKerrow A. 1991. Biogeochemical diversity along a riverside toposequence in Arctic Alaska. Ecol Monogr 61:415-35.

Giblin AE, Laundre JA, Nadelhoffer KJ, Shaver GR. 1994. Measuring nutrient availability in Arctic soils using ion exchange resins: a field test. Soil Sci Soc Am J 58:1154-62.

Government of Northwest Territories. 2019. Bathurst Caribou Range Plan. Environ Nat Resour, Government of the Northwest Territories, Yellowknife, NT. p. 86.

Harris I, Jones PD, Osborn TJ, Lister DH. 2014. Updated highresolution grids of monthly climatic observations-the CRU TS3.10 Dataset. Int J Climatol 34:623-42.

IPCC. 2013. Summary for policymakers; Detection and attribution of climate change: from global to regional. In: Climate change 2013: the physical science basis. Contribution of working Group I to the fifth assessment report of the Intergovernmental Panel on climate change. New York, NY: Cambridge University Press.

Ju J, Masek JG. 2016. The vegetation greenness trend in Canada and US Alaska from 1984-2012 Landsat data. Remote Sens Environ 176:1-16.

Kaarlejärvi E, Hoset KS, Olofsson J. 2015. Mammalian herbivores confer resilience of Arctic shrub-dominated ecosystems to climate change. Glob Chang Biol 21:3379-88.

Manseau M, Huot J, Crête M. 1996. Effects of summer grazing by caribou on composition and productivity of vegetation: community and landscape level. J Ecol 84:503-13.

Myers-Smith IH, Forbes BC, Wilmking $M$, Hallinger $M$, Lantz T, Blok D, Tape KD, Macias-Fauria M, Sass-Klaassen U, Lévesque E, Boudreau S, Ropars P, Hermanutz L, Trant A, Collier LS, Weijers S, Rozema J, Rayback SA, Schmidt NM, SchaepmanStrub G, Wipf S, Rixen C, Ménard CB, Venn S, Goetz S, Andreu-Hayles L, Elmendorf S, Ravolainen V, Welker J, Grogan P, Epstein HE, Hik DS. 2011. Shrub expansion in tundra ecosystems: dynamics, impacts and research priorities. Environ Res Lett 6:045509.

Myers-Smith IH, Hik DS. 2013. Shrub canopies influence soil temperatures but not nutrient dynamics: an experimental test of tundra snow-shrub interactions. Ecol Evol 3:3683-700.

Naito AT, Cairns DM. 2011. Relationships between Arctic shrub dynamics and topographically derived hydrologic characteristics. Environ Res Lett 6:045506.

Olofsson J, Oksanen L, Callaghan T, Hulme PE, Oksanen T, Suominen O. 2009. Herbivores inhibit climate-driven shrub expansion on the tundra. Glob Chang Biol 15:2681-93.

Pajunen AM, Oksanen J, Virtanen R. 2011. Impact of shrub canopies on understorey vegetation in western Eurasian tundra. J Veg Sci 22:837-46.

Plante S, Champagne E, Ropars P, Boudreau S, Lévesque E, Tremblay B, Tremblay J. 2014. Shrub cover in northern Nunavik: can herbivores limit shrub expansion? Polar Biol 37:611-19.

Porsild A, Cody W. 1980. Vascular plants of Continental Northwest Territories, Canada. Ottawa: National Museum of Natural Sciences, National Museums of Canada.

Ropars P, Boudreau S. 2012. Shrub expansion at the foresttundra ecotone: spatial heterogeneity linked to local topography. Environ Res Lett 7:015501. 
Ropars P, Lévesque E, Boudreau S. 2015. How do climate and topography influence the greening of the forest-tundra ecotone in northern Québec? a dendrochronological analysis of Betula glandulosa. J Ecol 103:679-90.

Ropars P, Angers-Blondin S, Gagnon M, Myers-Smith I, Lévesque E, Boudreau S. 2017. Different parts, different stories: climate sensitivity of growth is stronger in root collars vs. stems in tundra shrubs. Glob Chang Biol 23:3281-91.

Schuur EAG, McGuire AD, Grosse G, Harden JW, Hayes DJ, Hugelius G, Koven CD, Kuhry P, Lawrence DM, Natali SM, Olefeldt D, Romanovsky VE, Schaefer K, Turetsky MR, Treat CC, Vonk JE. 2015. Climate change and the permafrost carbon feedback. Nature 520:171-9.

Speed JDM, Austrheim G, Hester AJ, Mysterud A. 2011. Browsing interacts with climate to determine tree-ring increment. Funct Ecol 25:1018-23.

Tape K, Sturm M, Racine C. 2006. The evidence for shrub expansion in Northern Alaska and the Pan-Arctic. Glob Chang Biol 12:686-702.

Tape KD, Hallinger M, Welker JM, Ruess RW. 2012. Landscape heterogeneity of shrub expansion in Arctic Alaska. Ecosystems 15:711-24.

Thornton MM, Thornton, PE, Wei Y, Mayer BW, Cook RB, Vose RS. 2018. Daymet: monthly climate summaries on a 1-km grid for North America, version 3. Oak Ridge National Laboratory, Oak Ridge, TN. https://doi.org/10.3334/ORNLDAAC/1345.

Tremblay B, Lévesque E, Boudreau S. 2012. Recent expansion of erect shrubs in the Low Arctic: evidence from Eastern Nunavik. Environ Res Lett 7:035501.
Vankoughnett MR, Grogan P. 2016. Plant production and nitrogen accumulation above- and belowground in low and tall birch tundra communities: the influence of snow and litter. Plant Soil 408:195-210.

Walker MD, Wahren CH, Hollister RD, Henry GHR, Ahlquist LE, Alatalo JM, Bret-Harte MS, Calef MP, Callaghan TV, Carroll $\mathrm{AB}$, Epstein HE, Jónsdóttir IS, Klein JA, Magnússon B, Molau U, Oberbauer SF, Rewa SP, Robinson CH, Shaver GR, Suding KN, Thompson CC, Tolvanen A, Totland $\varnothing$, Turner PL, Tweedie CE, Webber PJ, Wookey PA. 2006. Plant community responses to experimental warmig across the tundra biome. Proc Natl Acad Sci USA 103:1342-6.

Young AB, Watts DA, Taylor AH, Post E. 2016. Species and site differences influence climate-shrub growth responses in West Greenland. Dendrochronologia 37:69-78.

Zamin TJ, Grogan P. 2012. Birch shrub growth in the low Arctic: the relative importance of experimental warming, enhanced nutrient availability, snow depth and caribou exclusion. Environ Res Lett 7:034027.

Zamin TJ, Grogan P. 2013. Caribou exclusion during a population low increases deciduous and evergreen shrub species biomass and nitrogen pools in low Arctic tundra. J Ecol 101:671-83.

Zamin TJ, Bret-Harte M, Grogan P. 2014. Evergreen shrubs dominate responses to experimental summer warming and fertilization in Canadian mesic low arctic tundra. J Ecol 102:749-66.

Zamin TJ, Côté S, Tremblay JP, Grogan P. 2017. Experimental warming alters migratory caribou forage quality. Ecol Appl 27 (7):2061-73. 